\title{
Childhood Consultation Rates in General Practice - Factors Associated with the Variations in Attendance; A Review
}

\author{
Maj A J Leach \\ MB ChB, Msc(Med), MRCGP, DRCOG, RAMC
}

\section{Berlin Group Practice, BFPO 45}

SUMMARY: General Practitioners catering for Service families need to be aware of the multiple influences on patien $\frac{\overline{\bar{n}}}{\bar{\hbar}}$ consultation. The children who attend frequently are those who have already been ill and those that attend a nurser $\vec{D}$ school. The mother is influential if she has had experience in looking after children, if she has had employment out of the home and if her formal education was poor. The psychological state of the mother has been shown to have an impace? and to be linked to the childhood consultation rate. This psychological state could well be influenced by frequent lif $\vec{P}$ events such as moving house and absence from the home of the spouse.

\section{Introduction}

Over the last few years the consultation rates for children visiting their General Practitioner has increased both for males and females. Between 1972 and 1987 the General Household Survey (1) showed that in the two weeks during the survey, there was an increase in consulting from $13 \%$ to $25 \%$ and from $15 \%$ to $21 \%$ for boys and girls respectively. Similarly Cartwright (2) reported that $33 \%$ of children under two years in age and $21 \%$ aged 2-4 years had consulted their General Practitioner greater than five times in the previous year. Children are thus a significant part of a GP's workload. From military practices, Sidebotham (3) reported a higher consultation rate from his Army practice in Germany as compared with a civilian practice in Devon. The mean consultation rate for Service children was 6.78 compared with 4.31 from Devon, a statistically significant difference. Similarly Grundy-Wheeler reported a consultation rate of 5.17 in 1986 from all patients in Osnabruck (4), this is higher than the national average of 3.4 (5). Other authors have commented upon the specific problems that Service families have. This includes the stresses of frequent moves, living away from relatives and often living in a foreign country (6).

The aim of this review is to discuss the reasons why children are brought to their General Practitioner including the factors which have been shown to be influential in consulting behaviour.

\section{Consultation rates}

A consultation can be defined as "an occasion on which a patient receives professional advice or help or treatment from his doctor" (7). The consultation may be direct (doctor and patient meet) or indirect (by telephone or third party). The main sources of information are the annual General Household Survey which shows a series of measures over a two week period (8) and the General Practice morbidity returns which are continued over twelve months $(5,9)$.

The second National Morbidity survey (5) showed that one quarter of the total workload of the practices was for children under the age of fifteen years. The survey also reported that annually $90 \%$ of children under five were taken to see their general practitioner.

There is a perception from some doctors that patientse come to the doctor inappropriately and on too manye occasions. This is not shown by the evidence. Hannay $\frac{1}{N}$ (10) in his study from Glasgow found that the majorityo of subjects did nothing about the majority of their? symptoms. Fifteen percent consulted family membe్ts and $10 \%$ asked specific questions of dentists, chirop dists or opticians. Few symptoms were referred $\bar{\omega} 00$ friends, nurses or health visitors. Pattison et al $(\mathbb{f}))^{\mathbb{D}}$ studied mothers in Newcastle-upon-Tyne. Diartesco recorded symptoms on $75 \%$ of days, but only $6 \%$ \& mothers sought professional advice. Variables whish predicted whether the child was brought to the doceiro were the total number of symptoms in an illness episode and the mother's previous experience with babies. Mothers who had looked after a baby before (other thano their own) were more likely to consult when their own child was ill. Other studies have confirmed that the ex $\overrightarrow{3}$ tent of the illness is important. Positive predictors have included high temperature, loss of appetite, excessive crying, rash, diarrhoea, lethargy, extent of distress and difficulty in breathing $(11,12)$.

Factors other than the physical have been shown to be predictors of childhood consultations. These have in cluded; if the child was aged less than one year; the father unemployed; absence of a family car and the ac commodation rented (13). Children who go to preschool nursery have also been shown to consult more frequently, but no increase in infectious disease was noted. The authors presumed that the children of the mothers who worked, were brought more frequentlyo because the mother wanted to avoid having time of work.

Campion and Gabriel (14) found that the most im portant variable that predicted a high consulting pattern S was the presence of a previous illness. Not only dof children attend when they are ill, but continue to do sot more frequently after the illness. Higher consulting 
families were significantly poorer and the mothers had less formal education. Morrison et al (15) analysed the factors that contributed to why children consulted frequently out of hours. The mothers of frequent attenders were more likely to be poorer, single or divorced and to have attained a lower educational level.

In view of the fact that parents and in particular mothers, tend to make the decisions as to when their child should see the doctor (12) is there any evidence that the psychological state of the parent affects their child's consultation rate? Leach (16) found in a military practice that the childhood consultation rate was linked to the mother's score on the General Health Questionnaire, a measure of anxiety and depression of recent origin. Other authors have found similar results $(17,18,19)$. In addition O'Brien found some evidence that psychological morbidity was higher in some sections of the Army that would be expected by their social class status (20).

\section{Military Practice}

Few studies have addressed the reasons behind the higher consultation rate found in military practices. Extrapolation is thus necessary from civilian investigations. The higher consultation rates for children could be explained by the fact that many Service personnel and their families come from some of the more socially disadvantaged parts of the United Kingdom. An extensive literature search has not found a study to prove this hypothesis.

Military families by definition are expected to move frequently and often at relatively short notice. Life event literature points towards the fact that moving house is one of the most stressful events which causes significant psychological morbidity $(21,22)$. In addition separation from a spouse has been shown to produce problems. Pearlman describes a psychological crisis that occurred in the spouses of submariners. This was found even if repeated separations had been endured (23). Comments such as "Why does he really have to go" and "I'll never live through the three months without him" are familiar themes. Other factors such as the absence of other family members, lack of pharmacists and the overall proverty of reservoirs of health information with whom a mother can consult before attending the doctor have been shown to be influential (4). Berkman and Syme (24) found that people who lacked social support had higher levels of morbidity and mortality and although it is presumed that military families tend to support each other, this may be an oversimplification. Similarly Brown and Harris found a clear relationship between experiencing a life event and the onset of a depressive disorder, although the illness was dependant upon various "vulnerability factors" (25).

\section{REFERENCES}

1. General Household Survey. 1987. HMSO.
2. Cartwright A. Patients and their doctors: a study of general practice. Institute of Community Studies. 1967. Routlege and Kegan Paul.

3. Sidebotham C F. Child consultation rates in service families. A comparison with civilians. Practitioner. 1985; 229: 625-627.

4. GRUNDY-WHEELER N J. Out of hours attendance in an Army practice. Br J Gen Pract 1991; 41: 210-212.

5. Royal College of General Practitioners, Office of Population Censuses and Surveys and Department of Health and Social Security. Morbidity statistics from general practice. Third National Survey, 19811982. London: HMSO. 1986.

6. VINCENTI G E. Service families: a new perspective for the general practitioner. Br J Gen Pract 1990; 40: $78-80$.

7. Research Unit of the Royal College of General Practitioners. A general practice glossary. $J R$ Coll Gen Pract 1973; 23 (3).

8. Office of Population Censuses and Surveys Social Survey Division. The General Household Survey. Introductory report. London: HMSO. 1973.

9. Royal College of General Practitioners, Office of Population Censuses and Surveys and Department of Health and Social Security. Morbidity statistics from general practice. Second National Survey. 1970-1971. London: HMSO. 1974.

10. HanNay D R. The Symptom Iceberg. A study o community health. 1979. London. Routlege an Kegan Paul.

11. Pattison C J, Drinkwater C K, Downham M A $\mathrm{S}$. Mother's appreciation of their children symptoms. J R Coll Gen Pract 1982; 32: 149-162.

12. Field S, Draper J, Hare M J. Babies' illness from parents' point of view. Matern Child Hlth. 1983; (6): 252-256.

13. WyKe S, Hewison J, Russell I T. Respiratory illness in children: what makes parents decide to consult. Br J Gen Pract 1990; 40: 226-229.

14. Campion P D, Gabriel J. Child consultation patterns in general practice comparing "high" and "low" consulting families. $\mathrm{Br}$ Med $J$ 1984; 288: 1426-1428.

15. Morrison J M, Gilmour H, Sullivan F. Children seen frequently out of hours in one general practice. Br Med J 1991; 303: 1111-1114.

16. LEACH A J. Master of Science Degree Dissertation. University of London. 1992.

17. Campion P D, Gabriel J. Illness behaviour in mothers with young children. Soc Sci Med 1985. 20 (4): 325-330.

18. BROWN G W, Davidson S. Social class, psychiatric disorder of mother and accidents to children. Lancet 1978; 1: 378-380.

19. Fitzgerald M, McGee H M. Psychological health status of mothers and admission of children to hospital for gastroenteritis. Fam Pract 1990; 7 (2): 116120.

20. O'BriEn L S. Psychiatric Morbidity in a Military General Practice. JR Army Med Corps 1985; 131: 16-18.

21. HoOper, INEICHen B. Adjustment to moving: a follow up study of the mental health of young 
families in new housing. Soc Sci Med 1979; 13: 163168.

22. Holmes $\mathbf{T} \mathbf{H}, \mathbf{R a h e} \mathbf{R} \mathbf{H}$. The social readjustment scale. J Psychol Res 1967; 11: 213-218.

23. Pearlman C A. Separation reactions of married women. Am J Psychiatry 1970; 126: 70-74.
24. BERKMAN L F, Syme S L. Social networks, host re-sistance and mortality: A nine year follow-up study of Almeda county residents. Am J Epidemiol 1979; 109 (2): 186-203.

25. Brown G W, Harris T. The Social Origins of Depression: A study of Psychiatric Disorder in Women 1978. Tavistock. London. 